\title{
Garnets in a Polymict Xenolith from the Bultfontein Mine, South Africa: New Preliminary Geochemical and Textural Data
}

\author{
Wyatt, B.A. ${ }^{1}$, Morfi, L. ${ }^{2}$, Gurney, J.J. ${ }^{3}$, Pearson, N.J. ${ }^{4}$, and Griffin, W.L. ${ }^{4}$
}

1. Stockdale Prospecting Ltd., P.O. Box 126, South Yarra, Melbourne, VIC 3183, Australia

2. Dept. of Geology and Geophysics, Grant Institute, West Mains Road, Edinburgh, EH9 3JW, U.K.

3. Dept. of Geological Sciences, University of Cape Town, Rondebosh 7700, Cape Town, South Africa

4. GEMOC National Key Centre, School of Earth Sciences, Macquarie University, NSW 2109, Australia

\section{Introduction}

Polymict xenoliths from the Bultfontein kimberlite, South Africa have previously been described in detail by Lawless (1978), Lawless et al. (1979) and Wyatt and Lawless (1984). These unusual xenoliths comprise a disequilibrium assemblage of peridotitic and eclogitic rock fragments and minerals cross-cut and cemented by veins of ilmenite, phlogopite, rutile and sulphides. The xenoliths have been interpreted as remnant, tectonically emplaced conduit breccia associated with the migration of kimberlitic fluids. The material was sampled at about $83 \mathrm{My}$ (Lawless et al., 1979).

These rocks are obvious candidates for a study of mantle metasomatism, and some preliminary trace element analyses of garnets in one of the xenoliths (BD2394) are presented here. The major elements were analysed at Macquarie University using a Cameca SX50 microprobe, and the trace elements on the ion probe facility at Edinburgh University.

\section{Textures and Major Element Chemistry}

One of the purple peridotitic garnets in BD2394 is surrounded by a $0.1 \mathrm{~mm}$ corona of orange garnet which is clearly an overgrowth. Present in the same sample is some invasive material, resembling a melt, and which now comprises an intergrowth of subhedral orange garnets, olivine, orthopyroxene, ilmenite and phlogopite (Figure 1). Similar areas were termed 'rock clasts' by Lawless et al.(1979).

Some of the garnet compositions which were also analysed for trace elements are given in Table 1. As noted by Lawless et al. (1979), the rock comprises a variety of garnets including $\mathrm{Cr}_{2} \mathrm{O}_{3}$-rich peridotitic, low $\mathrm{Cr}_{2} \mathrm{O}_{3}$ megacrystic and eclogitic varieties (Table 1). None of the large garnets, including the rimmed garnet (G1 in Figure 1), are compositionally zoned. The orange garnet overgrowth, and the small subhedral garnets comprising the invasive area (Figure 1), although slightly more variable, have low $\mathrm{Cr}_{2} \mathrm{O}_{3}$ megacrystic compositions (Table 1), and compare closely to megacrystic garnets from other localities such as Jagersfontein, Monastery, Lekkerfontein, (see Hops et al., 1992).

\section{Trace Elements}

The trace elements patterns of some of the garnets are given in Figures 2 and 3. $\mathrm{The} \mathrm{Cr}_{2} \mathrm{O}_{3}$ rich garnets are all LREE depleted and have HREE contents typical of lherzolitic garnets (eg. Hoal et al., 1994). Two of the peridotitic garnets (Nos. 1 and 5, Table 1) show slight depletion from Sm to Lu, but the sinusoidal patterns displayed by some depleted garnets (Hoal et al., 1994) is not evident. One of these garnets (No.5, Table 1, Figure 2) shows minor HREE enrichment in the rim relative to the core, suggestive of some interaction with a fluid phase. Two of the large yellow eclogitic garnets are also LREE depleted showing progressive enrichment in HREE, but are unzoned.

The orange garnet rim surrounding the peridotitic garnet and the subhedral garnets in the fine grained invasive area are almost identical being LREE depleted and HREE enriched (Figure 3). 
This REE pattern is very similar to low $\mathrm{Cr}_{2} \mathrm{O}_{3}$ garnets reported by Fedorowich et al. (1995) from the Frank Smith (South Africa) and Schaffer (Wyoming, USA) kimberlites.

\section{Discussion}

This preliminary study has shown that the polymict xenolith (BD2394), in spite of comprising a wide variety of garnet compositions, displays no evidence of major element re-equilibration, and minimal indication from the trace elements of reaction with the ilmenite-phlogopite-sulphide fluid phase that has infiltrated and cemented the xenolith. These data provide further evidence that the formation of the polymict xenoliths clearly was a transient event, very likely associated with the generation of the kimberlite, probably as an immediate precursor (Lawless et al., 1979; Wyatt and Lawless, 1984).

It is our view that the fine intergrowth of orange subhedral garnets, orthopyroxene, olivine, ilmenite and phlogopite (Figure 1) may either be the high pressure product of a basaltic partial melt generated and crystallised more or less in-situ, or an introduced melt that has invaded the polymict melange. This material may correspond to the source of the megacrystic garnets found in kimberlites and provides support for models of Harte (1983) and Hops et al. (1992) that these garnets are related to a basaltic magma. Whether this magma is a product of short duration partial melting within the polymict assemblage or is in fact introduced magmatic material (possibly related to a plume?) will require further evaluation of these data

\section{References}

Fedorowich, J.S., Jinesh, C.J., and Kerrich, R., 1995, Trace-element analysis of garnet by laserablation microprobe ICP-MS: Canadian Mineral., 33, p. 469-480.

Harte, B., 1983, Mantle peridotites and processes: the kimberlite sample: In Hawkesworth, C.J., and Norry, M.J., Continental Basalts and Mantle Xenoliths, p. 46-91.

Hoal, K.E.O., Hoal, B.G., Erlank, A.J., and Shimizu, N., 1994, Metasomatism of the mantle lithosphere recorded by rare earth elements in garnets: Earth Planet. Sci. Lett., 126, p.303-313.

Hops, J.J., Gurney, J.J., and Harte, B., 1992, The Jagersfontein Cr-poor megacryst suite - towards a model for megacryst petrogenesis: Jour. Volcanology and Geothermal Res., 50, p. 143-160.

Lawless, P.J., 1978, Some aspects of the mineral chemistry of the peridotitic xenolith suite from the Bultfontein Diamond Mine, Kimberley, South Africa: Unpub. PhD. Thesis, Dept. of Geochemistry, Univ. of Cape Town, 193p.

Lawless, P.J., Gurney, J.J, and Dawson, J.B., 1979, Polymict Peridotites from the Bultfontein and De Beers Mines, Kimberley, South Africa, In: Boyd, F.R., and Meyer, O.A. (Eds.), Proc. $2^{\text {nd }}$ Kimb. Conf., Vol. 2, p. 145-155.

Wyatt, B.A., and Lawless, P.J., 1984, Ilmenite in polymict xenoliths from the Bultfontein and De Beers Mines, South Africa: In Kornprobst, J. (Ed.), Proc. $3^{\text {rd }}$ Kimb. Conf., Vol. II, p. 43-56.

Figure 1. Small part of slide BD2394 showing what is interpreted as an melt (pale grey) invasive into a polymict melange (dark grey). Only the obvious subhedral orange garnets (low $\mathrm{Cr}_{2} \mathrm{O}_{3}$ megacryst composition) are shown (medium grey). Nos. 1, 2 etc. refer to analyses in Table 1.

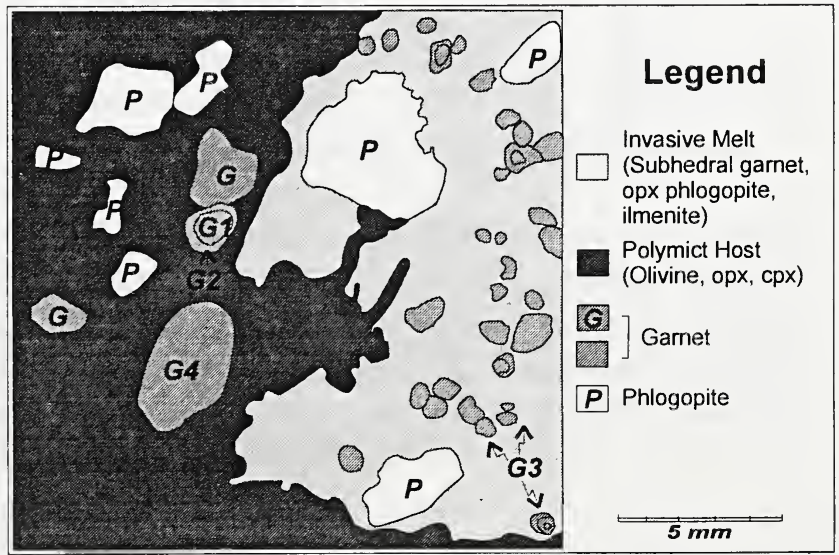


Table 1

\begin{tabular}{|c|c|c|c|c|c|c|c|c|}
\hline Anal. No. & 1 & 2 & 3 & 4 & 5 & 6 & 7 & 8 \\
\hline Anal. Ref. No & BW1GT101 & BW1GT103 & BW1GTA0 & BW1GT30 & $\mathrm{BW} 2 \mathrm{GT} 101$ & BW2GT201 & BW2GT30 & BW2GT401 \\
\hline Slide & $\mathrm{S} 14 / \mathrm{FC} / 1$ & $\mathrm{~S} 14 / \mathrm{FC} / 1$ & $\mathrm{~S} 14 / \mathrm{FC} / 1$ & $\mathrm{~S} 14 / \mathrm{FC} / 1$ & $\mathrm{~S} 14 / \mathrm{FC} / 2$ & $\mathrm{~S} 14 / \mathrm{FC} / 2$ & $\mathrm{~S} 14 / \mathrm{FC} / 2$ & $\mathrm{~S} 14 / \mathrm{FC} / 2$ \\
\hline Grain & Gt-1 & Gt-1 & Gt 4-8 & Gt-3 & Gt-1 & $\mathrm{Gt}-2$ & Gt-3 & $\mathrm{Gt}-4$ \\
\hline Description & $\begin{array}{c}\text { Purple - } \\
\text { Orange rim }\end{array}$ & $\begin{array}{c}\text { Orange rim } \\
\text { on Gt-1 }\end{array}$ & $\begin{array}{c}\text { Orange } \\
\text { Subhedral }\end{array}$ & Yellow & Purple & Purple & Purple & Yellow \\
\hline Paragenesis & Peridotite & Megacryst & Megacryst & Eclogite & Peridotite & Peridotite & Peridotite & Eclogite \\
\hline No. Points & 10 & 10 & 12 & 8 & 11 & 21 & 18 & 17 \\
\hline $\mathrm{SiO}_{2}$ & 42.12 & 41.86 & 41.59 & 40.46 & 41.20 & 40.93 & 41.72 & 39.86 \\
\hline $\mathrm{TiO}_{2}$ & 0.11 & 1.24 & 1.29 & 0.22 & 0.12 & 0.25 & 0.34 & 0.22 \\
\hline $\mathrm{Al}_{2} \mathrm{O}_{3}$ & 20.62 & 21.37 & 21.49 & 22.42 & 17.90 & 20.19 & 20.92 & 22.17 \\
\hline $\mathrm{Cr}_{2} \mathrm{O}_{3}$ & 3.94 & 1.04 & 0.82 & 0.13 & 7.09 & 3.17 & 3.19 & 0.07 \\
\hline $\mathrm{FeO}$ & 6.51 & 9.72 & 9.47 & 16.91 & 7.03 & 10.87 & 6.75 & 14.96 \\
\hline $\mathrm{MnO}$ & 0.28 & 0.29 & 0.27 & 0.40 & 0.29 & 0.33 & 0.28 & 0.37 \\
\hline $\mathrm{MgO}$ & 21.60 & 21.58 & 21.90 & 16.13 & 20.34 & 18.42 & 21.72 & 13.00 \\
\hline $\mathrm{CaO}$ & 5.03 & 4.41 & 3.19 & 3.24 & 5.40 & 5.50 & 4.72 & 8.85 \\
\hline $\mathrm{Na}_{2} \mathrm{O}$ & 0.04 & 0.08 & 0.07 & 0.10 & 0.05 & 0.03 & 0.06 & 0.07 \\
\hline $\mathrm{K}_{2} \mathrm{O}$ & 0.02 & 0.00 & 0.01 & 0.02 & 0.00 & 0.01 & 0.01 & 0.00 \\
\hline $\mathrm{NiO}$ & 0.02 & 0.02 & 0.02 & 0.03 & 0.00 & 0.02 & 0.01 & 0.02 \\
\hline Total & 100.29 & 100.61 & 100.14 & 100.05 & 99.52 & 99.72 & 99.70 & 99.59 \\
\hline
\end{tabular}

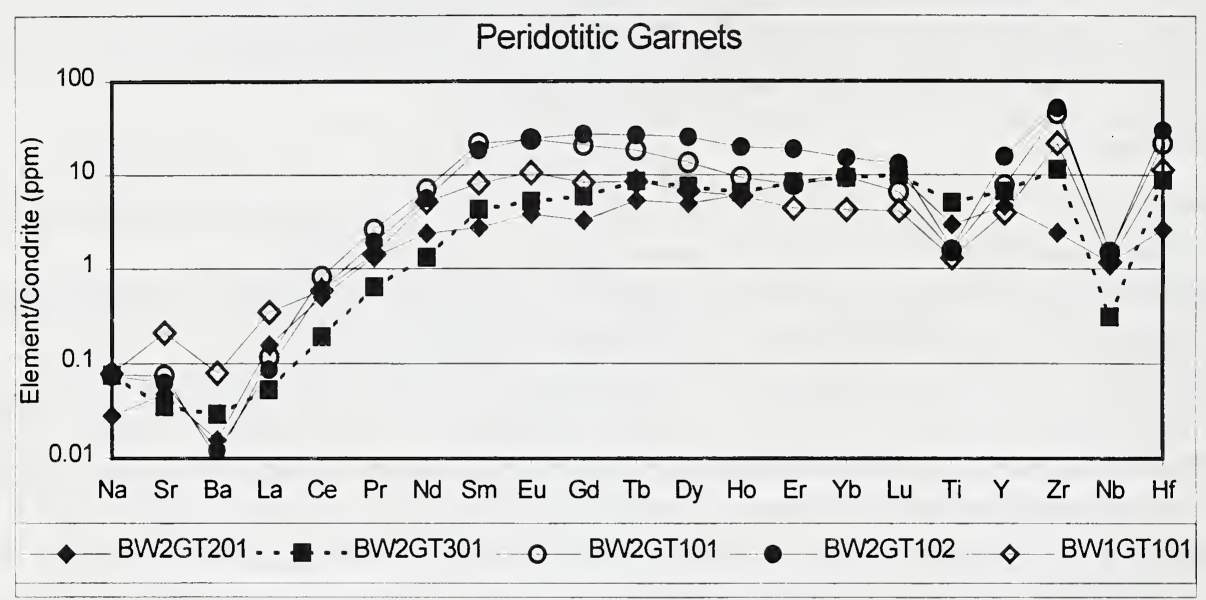

Figure 2. See Table 1 for grain identification.

Eclogitic and Megacrystic Garnets

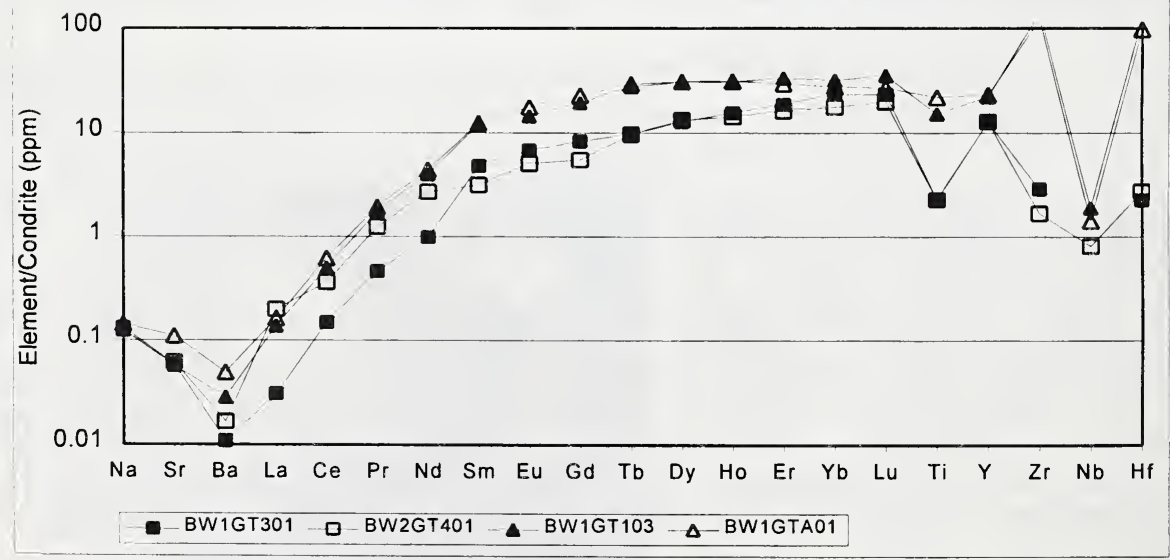

Figure 3. See Table 1 for grain identification. 